(The 3rd ICBS-2013)

\title{
ABUNDANCE AND SIGHTING FREQUENCY OF BIRDS IN SENDI - GAJAH MUNGKUR TRACK, TAMAN HUTAN RAYA RADEN SOERJO, MOJOKERTO REGENCY
}

Windri Hermadhiyanti, Haris Eka Pramudita, Heru Cahyono, Rani Arifiantari, Muhammad Ardiansyah, Ana Sa'adah, Charina Ramadhani, Diany Ragil MientyasNingrum, Riri

Wiyanti Retnaningtyas, Bima Diwanata

Malang Eyes Lapwing (MEL) Bird Study Group, Jl. Semarang 5, Malang, Indonesia 65145

E-mail: hariseka31@yahoo.co.id: hermadhiyantiwindri@gmail.com

\begin{abstract}
Sendi - Gajah Mungkur is one of conservation area in Taman Hutan Raya Raden Soerjo, Mojokerto Regency. This is region mostly composed by tropical rainforest with altitude of 1067 - 1174 amsl with rich biodiversity including orchids, mammals, and birds. Some evidence concerning Taman Hutan Raya Raden Soerjo's richness are some reports and documentations about the Zoothera andromedae, Ficedula narcis, and Arborophila javanica as new records in West Java. This research is done to determine the abundance and sighting frequency of birds in Sendi - Gajah Mungkur track, Taman Hutan Raya Raden Soerjo, Mojokerto Regency using modified line transect method. Species with the most abundance and sighting frequency are Collocalia linchi, Zosterops palpebrosus, and Dicaeum sanguinolentum.
\end{abstract}

Key words: Abundance, Sighting Frequency, Sendi, Gajah Mungkur, Taman Hutan Raya Raden Soerjo

\section{INTRODUCTION}

Indonesia has once been dubbed as the Emerald of the Equator due to its large forest area throughout the country. The forest is not only widely regarded as the world's lungs, but also the country's most precious heritage. It conserves biodiversity of many kinds of flora and fauna, which help make Indonesia becomes one of the countries with mega biodiversity in the world. One of the Indonesia's forests that is rich in biodiversity is Tahura R. Soerojo, located at the eastern part of Java. (Tahura stands for "Taman Hutan Raya," which can be roughly translated as "Grand Forest Park.")

Tahura R. Soerjo is one of the water catchment areas in East Java. Located at the foot of Mount Welirang and Arjuna, this area stands about 1067 - 1174 meters above the sea level. It has a total land mass of $27,868.30 \mathrm{Ha}$ and is considered as the third biggest Tahura in Indonesia (Foto Biodiversitas, 2012). Aside from its considerably wide area, this forest's condition is that of a tropical rain forest that has several springs which allow the biodiversity to remain high. Tahura R. Soerjo has as many as 163 springs that spread across 13 subdistricts (Foto Biodiversitas, 2012). The springs come from the Brantas River, the second longest river of Java. One instance of the biodiversity that belongs to this forest is the bird species, namely by the new discovery of several species in East Java, such as Zoothera andromedae, Ficedula narcis, and Arborophila javanica. The area includes some regions of Cangar, Sendi, Gajah Mungkur, Tretes, and Sendi. Gajah Mungkur itself is one of the area's regions that also contain many species of birds. Unfortunately, the information regarding the species is remotely small. 
Birds are one of the unique forms of wildlife. Aside from their fur color, voices and living habits, they also have a significant role as indicator of environmental health. In some circumstances, birds can be used as excellent barometers of wider environmental health, particularly when such assessments use summarized data from a wide range species (Bibby, 1999 In: Gregory et al., 2004). Rudyanto (2007) also stated that birds can be used as environmental health indicator that possesses high level of biological diversity, since birds can virtually be found in any kinds of habitat, relatively easy to identify and are sensitive to environmental changes.

Birds are prone to be used as targets for poaching. Up until now, there are many endemic and law-protected birds that have fallen victims at the hands of irresponsible poachers. Aside from the illegal hunting, the destruction of the birds' habitat (deforestation, for instance) can also cause the numbers of certain kinds of birds to decrease. These problems apparently happen at several regions of the Tahura. If the problems persist, several species of bird will slowly become endangered or even extinct. Therefore, some acts of conservation need to be executed in order to prevent the worst from ever happening.

Surveying the birds' whereabouts is one of the efforts that can be exercised in order to find out and maintain the number of certain species at certain areas. The data obtained from the survey can be used as references for future use. Not only that, the study of the birds' species is also need to be done more intensively so that the sustainability can be kept safely.

\section{MATERIALS AND METHODS}

\section{Collection and Identification Birds}

The data retrieval is done along the line track of Sendi - Gajah Mungkur, Taman Hutan Raya (Grand Forest Park) Raden Soerjo, Mojokerto Regency at May $17^{\text {th }}-20^{\text {th }} 2013$ (Figure 1). The sample extracting is done four times by using modified line transect method. The observation begins at $6 \mathrm{AM}$ and ends at $9 \mathrm{AM}$. The retrieved data are the birds' species and the amount for each species. The line track is throughout $2 \mathrm{~km}$, divided into four observation points with the interval of $500 \mathrm{~m}$ for each point. The observation is done at each point for 30 minutes long, with the distance field of view is $20 \mathrm{~m}$ for each direction (left and right). The observation uses binocular and GPS. As for the measuring of abiotic component, the tools that are used consist of anemometer, luxmeter, and thermo-hygrometer. The identification of the birds' species is based on Mac Kinnon (1998)

\section{Data analysis}

The collected data are used to find out the abundance and the frequency. The index of abundance is obtained by using adopted calculation method from Krebs (1989):

$$
\text { Abundance }=\frac{\text { number of individuals for a species }(n i)}{\text { total number of individuals found }(N)} \times 100 \%
$$

As for calculating the frequency of occurrence, the method is using equation adopted from Misra (1968):

$$
\text { Frequency }=\frac{\text { number of stations where a species can be observed }}{\text { total number of stations }} \times 100 \%
$$




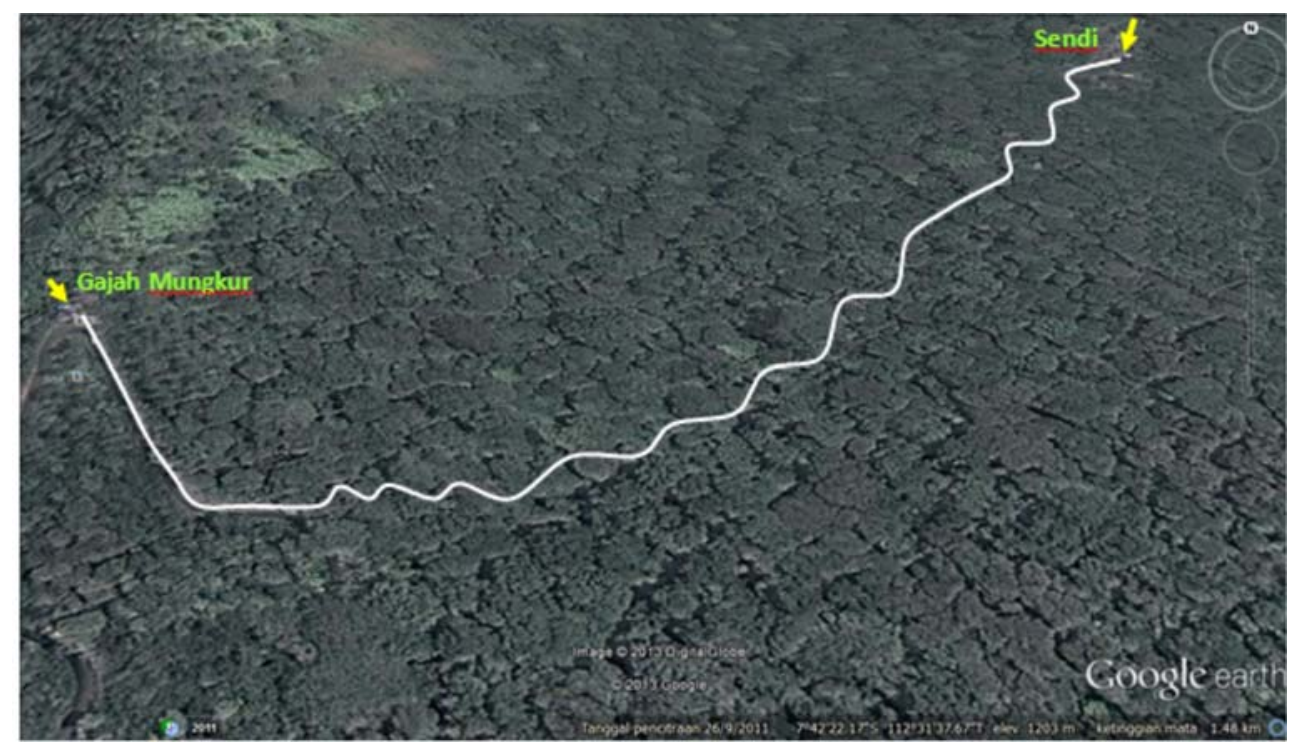

Figure 1. Research Location

\section{RESULT AND DISCUSSION}

From the four observation spots, some species such as Collocalia linchi, Zosterops palpebrosus, Dicaeum sanguinolentum, Rhyticeros undulatus, Parus major, Megalaima armillaris, Hemipus hirundinaceus, Pericrocotus miniatus, Ixos virescens, Megalaima australis, Aplonis panayensis, Macropygia unchall, Hirundo striolata, Pycnonotus goiavier, Eumyias indigo, Pycnonotus aurigaster, Splilornis cheela, Sitta azurea, Lophozosterops javanicus, Macropygia ruficeps, Bradypterus seebohmi, Eurylaimus javanicus, Megalaima javensis, Ictinaetus malayensis, Nicaetus bartelsi, Ficedula hyperythra, Pneopigia pusilla, Culicicapa ceylonensis, Pitta guajana, Melacocincla sepiarum, Sitta frontalis, Macropygia emiliana, Orthotomus sepium, Chalcophaps indica, Ducula lacernulata, Treron griseicauda, Pericrocotus cinnamomeus, Aethopyga mystacalis, Erythrura prasina are found. The collected data is analyzed to find the abundance and the relative frequency of the bird species found in the location. The abundance is the number of individual from each species that is found during the observation. The calculation of the relative abundance of the bird species in Sendi-Gajah Mungkur is presented in the table 1. Afterwards, the abundance index value is divided into three categories: high (>20\%), middle (15\%-20\%), and low $(<15 \%)$.

From the species abundance calculation, it is known that Collocalia linchihas the highest abundance index of 48,21917808 . The second highest abundance index belongs to Zosterops palpebrosus dan Dicaeum sanguinolentum with the abundance index of 4,657534247 .

The existence frequency of bird species in Taman Hutan Raya Raden Soerjo, Mojokerto Regency is presented in table 2. From the existence frequency calculation, known that Colocallia linchi has the highest existence index of $93,75 \%$. The second and the third highest existence frequency belong to Dicaeum sanguinolentum dan Zosterops palpebrosus with each index of $56,25 \%$ and $50 \%$. 
Table 1. Abundance of the bird species found in Sendi-Gajah Mungkur, Taman Hutan Raya Raden Soerjo, Mojokerto Regency.

\begin{tabular}{clc}
\hline No. & \multicolumn{1}{c}{ Spesies } & Abundance (\%) \\
\hline 1. & Collocalia linchi & 48,22 \\
2. & Zosterops palpebrosus & 4,66 \\
3. & Dicaeum sanguinolentum & 4,66 \\
4. & Rhyticeros undulatus & 4,11 \\
5. & Parus major & 3,01 \\
6. & Megalaima armillaris & 2,74 \\
7. & Hemipus hirundinaceus & 2,74 \\
8. & Pericrocotus miniatus & 2,47 \\
9. & Ixos virescens & 2,19 \\
10. & Megalaima australis & 2,19 \\
11. & Aplonis panayensis & 1,92 \\
12. & Macropygia unchall & 1,64 \\
13. & Hirundo striolata & 1,64 \\
14. & Pycnonotus goiavier & 1,64 \\
15. & Eumyias indigo & 1,37 \\
16. & Pycnonotus aurigaster & 1,37 \\
17. & Splilornis cheela & 1,10 \\
18. & Sitta azurea & 1,10 \\
19. & Lophozosterops javanicus & 1,10 \\
20. & Macropygia ruficeps & 1,10 \\
\hline
\end{tabular}

\begin{tabular}{clc}
\hline No. & \multicolumn{1}{c}{ Spesies } & Abundance (\%) \\
\hline 21. & Bradypterus seebohmi & 0,82 \\
22. & Eurylaimus javanicus & 0,55 \\
23. & Megalaima javensis & 0,55 \\
24. & Ictinaetus malayensis & 0,55 \\
25. & Nisaetus bartelsi & 0,55 \\
26. & Ficedula hyperythra & 0,55 \\
27. & Pneopigia pusilla & 0,55 \\
28. & Culicicapa ceylonensis & 0,55 \\
29. & Pitta guajana & 0,55 \\
30. & Melacocincla sepiarum & 0,55 \\
31. & Sitta frontalis & 0,55 \\
32. & Macropygia emiliana & 0,55 \\
33. & Orthotomus sepium & 0,55 \\
34. & Chalcophaps indica & 0,27 \\
35. & Ducula lacernulata & 0,27 \\
36. & Treron griseicauda & 0,27 \\
37. & Pericrocotus cinnamomeus & 0,27 \\
38. & Aethopyga mystacalis & 0,27 \\
39. & Erythrura prasina & 0,27 \\
& &
\end{tabular}

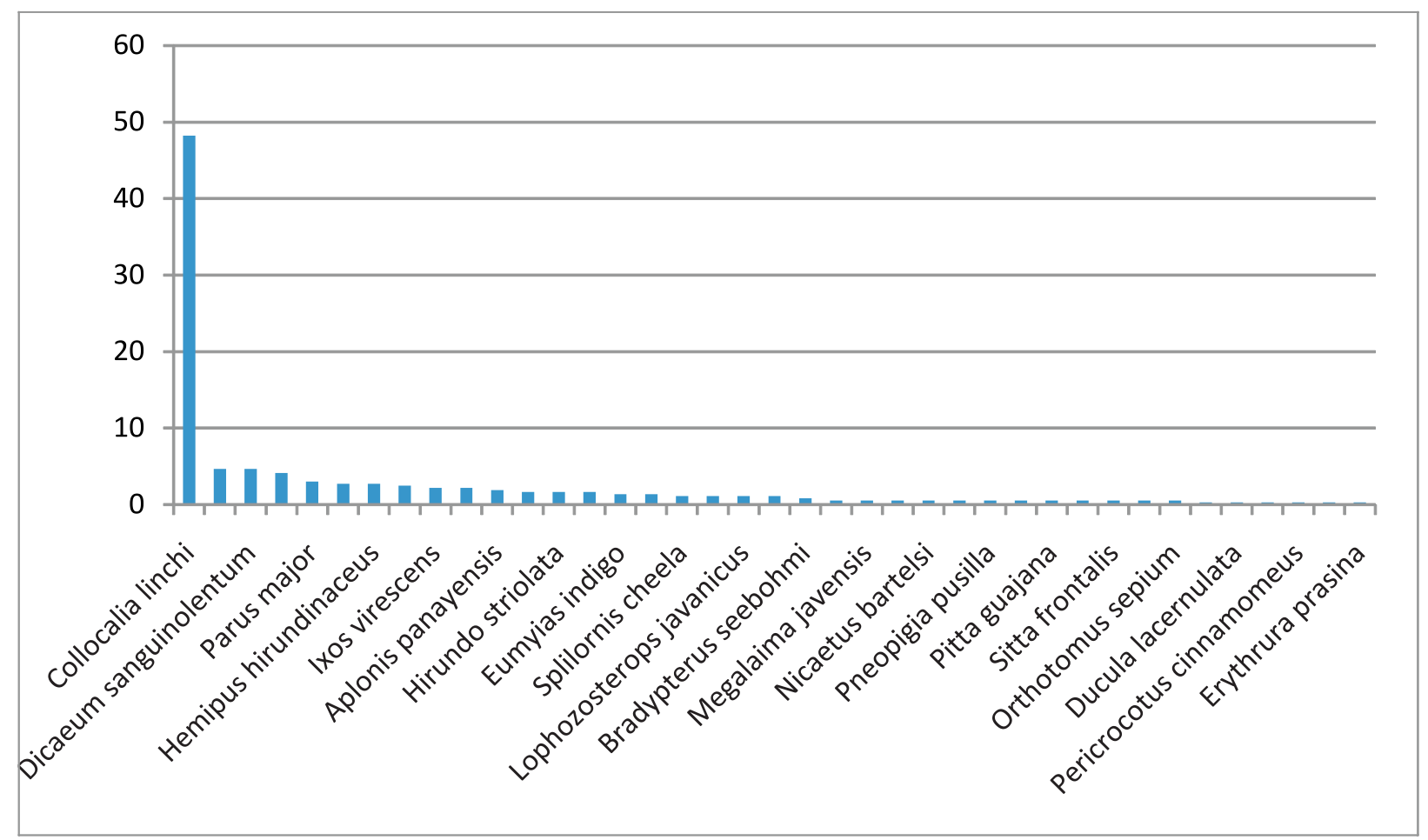

Based on Cahyono (2013), in Taman Hutan Raya Raden Soerjo, Mojokerto Regency was found less-recorded java-dwelling bird like Gracula religiosa, Dicaeum agile, Dicaeum chrysorrheum, Zoothera andromedae, Ficedula narcissina, Strix leptogrammica, Phodilus badius, and Buceros rhinoceros. 
Table 2. Freqency of the bird species found in Sendi-Gajah Mungkur, Taman Hutan Raya Raden Soerjo, Mojokerto Regency.

\begin{tabular}{clc}
\hline No. & \multicolumn{1}{c}{ Spesies } & Frequence (\%) \\
\hline 1. & Collocalia linchi & 93,75 \\
2. & Dicaeum sanguinolentum & 56,25 \\
3. & Zosterops palpebrosus & 50 \\
4. & Rhyticeros undulatus & 37,5 \\
5. & Macropygia unchall & 37,5 \\
6. & Megalaima armillaris & 37,5 \\
7. & Ixos virescens & 37,5 \\
8. & Parus major & 37,5 \\
9. & Megalaima australis & 37,5 \\
10. & Eumyias indigo & 31,25 \\
11. & Hemipus hirundinaceus & 31,25 \\
12. & Splilornis cheela & 25 \\
13. & Pycnonotus aurigaster & 18,75 \\
14. & Bradypterus seebohmi & 18,75 \\
15. & Pericrocotus miniatus & 18,75 \\
16. & Eurylaimus javanicus & 12,5 \\
17. & Sitta azurea & 12,5 \\
18. & Lophozosterops javanicus & 12,5 \\
19. & Megalaima javensis & 12,5 \\
20. & Ictinaetus malayensis & 12,5 \\
\hline
\end{tabular}

\begin{tabular}{llc}
\hline No. & \multicolumn{1}{c}{ Spesies } & Frequence (\%) \\
\hline 21. & Hirundo striolata & 12,5 \\
22. & Macropygia ruficeps & 12,5 \\
23. & Nicaetus bartelsi) & 12,5 \\
24. & Ficedula hyperythra) & 12,5 \\
25. & Pycnonotus goiavier & 12,5 \\
26. & Pneopigia pusilla & 12,5 \\
27. & Culicicapa ceylonensis & 12,5 \\
28. & Chalcophaps indica & 6,25 \\
29. & Ducula lacernulata & 6,25 \\
30. & Pitta guajana & 6,25 \\
31. & Treron griseicauda & 6,25 \\
32. Melacocincla sepiarum & 6,25 \\
33. & Pericrocotus cinnamomeus & 6,25 \\
34. Sitta frontalis & 6,25 \\
35. & Aplonis panayensis & 6,25 \\
36. & Macropygia emiliana & 6,25 \\
37. & Aethopyga mystacalis & 6,25 \\
38. & Erythrura prasina & 6,25 \\
39. & Orthotomus sepium & 6,25
\end{tabular}

\section{REFERENCES}

Cahyono, H. 2013. New Information About The Distribution of Less-Recorded Java-Dwelling Bird Species Found In Tahura Raden Soerjo, East Java. ICBS.

Foto Biodiversitas, 2012. Biodiversitas Indonesia - Bhinneka Flora Fauna Indonesia. FOBI, vol. $02 /$ no. 02.

Krebs,C.J. 1989. Ecology The Experimental Analysisof Distribution and Abundance. Harper and Rows Publication., New York.

Mackinnon, J., K. Phillips and B. van Balen. 1998. Burung - Burung di Sumatera, Jawa, Bali, dan Kalimantan. Puslitbang Biologi - LIPI/ BirdLife Indonesia., Bogor.

Mirsa, R. 1968. Ecology Workbook. Oxford and IBH Publishing Co., New Delhi.

Gregory, R.D., W.G. David, and F.D. Paul. 2004. Bird Cencus and Survey Technique. Without Publisher.

Rudyanto and W.M. Rombang. 2007. Daerah Penting Bagi Burung Jawa \& Bali. PKA/Birdlife International-Indonesia Programme, Bogor. 